\title{
Strategies of innovation in an ancient business: cases of the fountain pen industry
}

\section{Marcos Ferasso*}

Federal University of Parana, Av. Lothário Meissner, 632, Jd. Botânico, Curitiba - PR, 80210-170, Brazil

Email: admmarcos@admmarcos.adm.br

*Corresponding author

\section{Ivan Antonio Pinheiro}

Federal University of Rio Grande do Sul, R. Washington Luiz, 855, Centro Histórico, Porto Alegre - RS, 90010-460, Brazil

Email: iapinheiro@ea.ufrgs.br

\section{Christine da Silva Schröeder}

Federal University of Health Sciences of Porto Alegre, R. Sarmento Leite, 245, Porto Alegre - RS, 90050-170, Brazil Email: christine1004sch@gmail.com

\begin{abstract}
The introduction of the ballpoint pen and its consequent change in the prevalent fountain pen industry is presented as an empirical evidence of Christensen's disruptive technology theory. This research paper analyses the different innovation strategies adopted by the fountain pen industry to survive to the attack of ballpoint pen spread. To meet this objective, case studies of Waterman, Montblanc and Parker companies are discussed. The data, collected from secondary sources, indicate that the fountain pen industry had a great reduction in their sales and later stabilised at a lower level by stressing their positioning at the luxury goods market, but also adopting and transforming the new ballpoint technology. The analysis of this cases leads to the conclusion that the ballpoint pen is truly a good example of Christensen's disruptive technology because it contains all of Schumpeter's types of innovation.
\end{abstract}

Keywords: strategies of innovation; management of technology; ancient business; fountain pen industry; luxury goods market; Parker Pen Co.; Waterman Pen Co.; Montblanc Pen Co.

Reference to this paper should be made as follows: Ferasso, M., Pinheiro, I.A. and Schröeder, C.d.S. (2017) 'Strategies of innovation in an ancient business: cases of the fountain pen industry', Int. J. Economics and Business Research, Vol. 14, No. 1, pp.73-84. 
Biographical notes: Marcos Ferasso earned his Bachelor Diploma in Management from the University of the West of Santa Catarina, Brazil in 2002, his specialisation Diploma in Business Management from the University of the West of Santa Catarina, Brazil in 2005, specialisation Diploma in Local Development from the International Labour Organization/United Nations, Italy in 2006, and earned his MSc in Management from the Federal University of Rio Grande do Sul, Brazil in 2009, with an exchange period as a Visiting Researcher at the Euromed-Marseille Ecole de Management, France. Currently, he is a $\mathrm{PhD}$ candidate at the Graduate Program in Management, Federal University of Parana, Brazil with an exchange period as a Visiting Researcher at the Forsyth Technical Community College, USA. His research interests include innovation, knowledge management, clusters, small enterprises, strategy, local/regional development, and luxury market.

Ivan Antonio Pinheiro received his Bachelor in Statistics, Bachelor in Economics, MSc in Management in 1994 and Doctorate in Management in 2000 from the Federal University of Rio Grande do Sul, Brazil. Currently, he is a retired Professor from the School of Management - UFRGS. His current research interests include innovation management and public management.

Christine da Silva Schröeder received her Bachelor in Management, MSc in Management in 2005 and Doctorate in Management in 2009 from the Federal University of Rio Grande do Sul, Brazil. Currently, she is a Professor at the Federal University of Health Sciences of Porto Alegre. Her current research interests include strategic management, distance learning and public management.

This paper is a revised and expanded version of a paper entitled 'Strategies of innovation in an ancient business: cases of the fountain pen industry' presented at The 17th International Conference on Management of Technology - IAMOT, Dubai, UAE, 6-10 April 2008.

\section{Introduction}

The writing instruments market had a great change around the mid-20th century when the fountain pen industry was attacked by introduction of the ballpoint pen. The objective of this paper, based on theories of sustainable and disruptive innovations, is to analyse the different innovation strategies adopted by the fountain pen industry to survive to the attack of ballpoint pen spread.

The fountain pen industry started about the mid-19th century and sales continue to grow until the $1950 \mathrm{~s}$, when they had a great decline with the appearance of the ballpoint pen. Initially, the fountain pen industry reacted through a policy of price reduction. In the meantime, the ballpoint pen industry also had a price decline while the fountain pen seemed doomed to extinction. In fact, many enterprises did not survive, others were bought and a few giant companies remained. The fountain pen industry was able to make a comeback, not to the previous level, but to a steady level of sales that prevails until today. The paper presents the survival strategies used by three of the most prestigious and ancient fountain pen companies still in activity today (see Appendix).

This paper discusses Schumpeter's (1985) concepts of innovation, the theories of sustainable innovation (Christensen, 1999; Christensen and Raynor, 2003; Christensen, 
2004) and disruptive innovation (Utterback and Acee, 2005). It is followed by a brief presentation of the fountain pen and ballpoint history. Then, we present the three case studies of the strategies used by Waterman, Montblanc, and Parker. The data was collected from academic articles, industry history books, websites, and published interviews. It considers what can happen with long established enterprises when a new product is introduced in the market, forcing them to adopt new innovation strategies for products and markets. The final section presents the conclusions.

\section{Sustainable and disruptive innovation}

Schumpeter (1985) said that innovation can occur in the introduction of a new product, new production method, opening of a new market, acquisition of a new source of raw material or the half-manufactured goods or reorganise an industry. Meanwhile, Christensen (1999) classified innovations as sustainable and disruptive.

Sustainable innovation maintains a development trajectory on the established market by offering new attributes to products already known by consumers. This innovation tends to maintain a constant level of sales growth. According to Christensen and Raynor (2003), sustainable innovation occurs to meet the exigencies of sophisticated customers. There are some sustainable innovations in form of periodically improvements that enterprises can introduce on its own products.

Disruptive innovation introduces new and different products valued by consumers and tends to create new markets. A disruptive technology is typically cheaper, simpler to use versions of existing products that target low-end or entirely new customers. The theory of disruptive innovation underlines the situations in which organisations may utilise innovations in a relatively simple and convenient way and with low costs to generate growth to win over the powerful established enterprises (Christensen, 2004).

The disruptive technology theory presented by Christensen and modified by Utterback and Acee (2005) states that when there is a new entrant placing a new product in the market, established firms have greater survival odds. The basic problem seems to be that although they have competence to adopt the new technology they continue to make their heaviest commitments to the old technology, which reaches the zenith of their development only after they are mortally threatened. Those firms continue to make added commitments to developing old products even after their sales had begun to rapidly decline. Their explanation for this difficulty is that, decisions about allocating resources to old and new technologies within the organisation are loaded with implications for the decision makers; not only are old product lines threatened, but also old skills and positions of influence (Utterback and Acee, 2005).

Utterback and Acee $(2005$, p.4) said that "... to some extent the renewal of the old may in part be a function of its adopting and incorporating the new, but as a defensive measure ...". A second explanation is that: “... the resurgence of the old may be a function of picking up opportunities that have lain fallow when just incremental improvement seemed to suffice". They also present another alternative explanation: “... many market niches for an older technology may be protected for a long period of time. These would necessarily be the niches in which it has the greatest advantages over the disruptive technology ... Since improvement would have greater value in these niches, 
one might actually observe more rapid advance in the traditional technology for that reason".

All those concepts and theories can be applied to the fountain pen industry to explain what happened with this sector to be seeing in the next sections.

\section{Fountain pen versus ballpoint pen industry}

The fountain pen's design came after a thousand years of using quill-pens. Lewis Waterman patented the first practical fountain pen in 1884 (Lambrou, 2005). There were previous models but Waterman's was the first one not plagued by ink spills and other failures that left them impractical and hard to sell. The ink cartridge introduced around 1950 was a disposable, pre-filled plastic or glass cartridges designed for clean and easy insertion. They were an immediate success (Pennenlux, 2007). Around the same year, the ballpoint pen was launched in the market.

The decades that followed saw many technological innovations in the manufacture of fountain pens. Celluloid gradually replaced hard rubber, which enabled production in a much wider range of colours and designs. At the same time, manufacturers experimented with new filling systems. The inter-war period saw the introduction of some of the most notable models, such as the Parker Duofold and Vacumatic, Sheaffer's Lifetime Balance series, and the Pelikan 100 (Lambrou, 2005).

Laszlo Biro invented the ballpoint pen in 1938. Biro had noticed that the type of ink used in newspaper printing dried quickly, leaving the paper dry and smudge-free. He decided to create a pen using the same type of ink. The thicker ink would not flow from a regular pen nib and Biro had to devise a new type of point. He did so by fitting his pen with a tiny ball bearing in its tip. As the pen moved along the paper, the ball rotated picking up ink from the ink cartridge and leaving it on the paper. This principle of the ballpoint pen dates to an 1888 patent owned by John J. Loud for a product to mark leather. However, this patent was commercially unexploited. Laszlo Biro first patented his pen in 1938, and applied for a fresh patent in Argentina on June 10, 1943. Laszlo Biro and his brother Georg Biro immigrated to Argentina in 1940. The British Government bought the licensing rights to this patent for the war effort. The British Royal Air Force needed a new type of pen, one that would not leak at higher altitudes in fighter planes as the fountain pen did. Their successful performance for the Air Force brought the Biro pens into the limelight. Laszlo Biro had neglected to get a US patent for his pen and so, even with the ending of World War II, another battle was just beginning (Pennenlux, 2007).

Ballpoint pens guaranteed to write for two years without refilling, claimed to be smear proof. Reynolds advertised it as the pen 'to write under water'. Eversharp sued Reynolds for copying the design it had acquired legally. Nevertheless, the Reynolds' pen leaked, skipped and often failed to write. Eversharp's pen did not live up to its own advertisements. A very high volume of pen returns occurred for both Eversharp and Reynolds. The ballpoint pen fad ended - due to consumer unhappiness (Pennenlux, 2007).

BIC dominates the market. Parker, Sheaffer and Waterman, capture the smaller upscale markets of fountain pens and expensive ballpoints. Biro is still the generic name used for the ballpoint pen in most of the world. The Biro pens used by the British Air Force in World War II worked (Pennenlux, 2007). 
The fountain pen and ballpoint pen history had a different trajectory (Figure 1).

Figure 1 Sales of fountain pens and ballpoint pens - in millions of units (1929-1999) (see online version for colours)

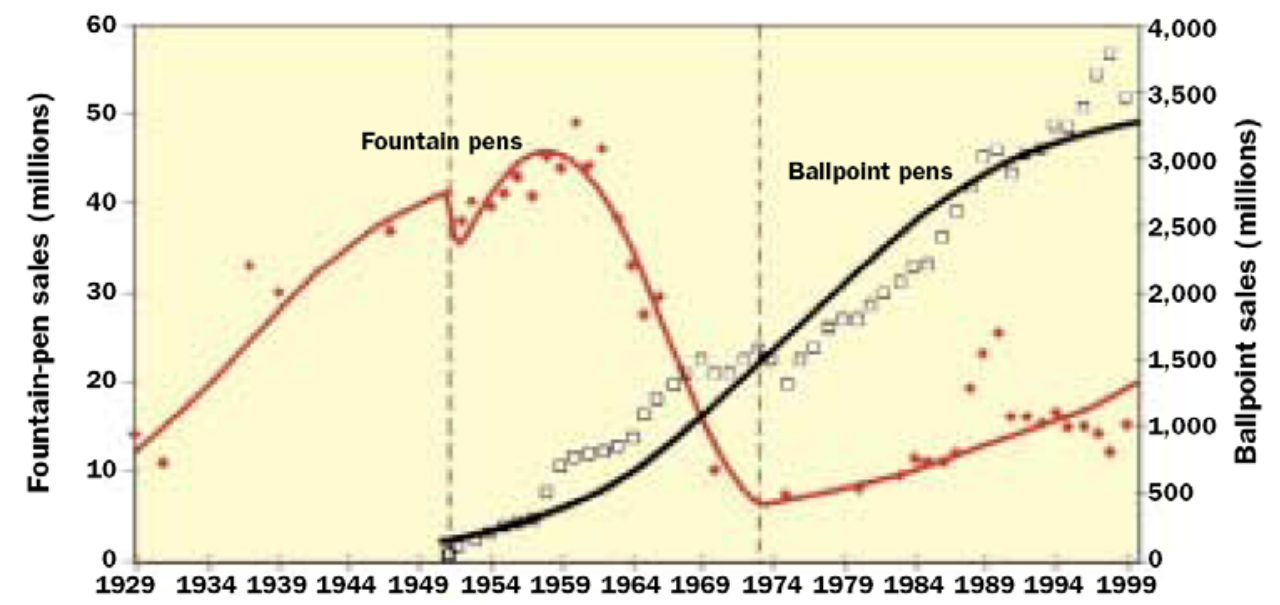

Source: Modis (2003, p.26)

The substitution of fountain pens for ballpoint pens as main writing instrument went through four distinct stages that we identified in Modis' (1997) figure data from various sources and that are explained according to our review of the literature.

1 Period 1929-1949 - Fountain pen was the most important writing instrument. After the crash of 1929, sales of fountain pen started to increase.

2 Period 1950-1958 - There was a decrease in the sales of fountain pens followed by a growth period that culminated in 1958 with largest ever number of fountain pen sold. It was during this period that the ballpoint pen market started to grow, mainly due the sales of the BIC Company.

The ballpoint pen can be characterised as what Christensen would call a disruptive technology that was introduced in the writing instruments market. The reaction of the fountain pen industry was to try with the same technology solely by decreasing the prices to win over the new competitor. Utterback and Acee (2005) explained long established industries tend to ignore the signs of the market and avoid changing an old and familiar technology. This fact is highlighted in the next period.

3 Period 1959-1974 - The fountain pens sales decreased to the lowest performance in 1974. Among the most prestigious companies listed by Narayanan (2005), five of them - Conklin, Thomas de la Rue, Kaweco, Mabie Todd, Moore - disappeared from the market (see the Appendix). This period showed a change in the strategy used by the surviving fountain pen companies which started to incorporate ballpoint pens among their products.

As Utterback and Acee (2005) explained, the incorporation of the new technology can be a defensive strategy that helps to survive the attack of a disruptive technology. This was the case of the fountain pen companies that survived. 
4 Period 1987-present - The fountain pen industry positions itself in the luxury goods market niche and their sales stabilised. Presently, according to Pennenlux (2007), “The highly popular modern version of Laszlo Biro's pen, the BIC Crystal, has a daily worldwide sales figure of 14,000,000 pieces".

Although data was not found for sales in recent years it is quite probable that the number of sold fountain pens stabilised, while their unit price substantially increased justified by the number of incremental innovations presented annually by the industry. The innovations in the ballpoint pen industry are also substantially numbered but the price is continually going down. These differences are determined by the different market niches that the two types of pens are in whose details are discussed in the following sections when we explore how the fountain pen sector reacted to the introduction of the ballpoint pen. For this purpose, as announced, we review the history of three companies that are widely known as giants of the fountain pen industry: Waterman, Montblanc, and Parker.

\section{Cases of the fountain pen industry}

\subsection{Waterman Company}

Before setting up his first 'factory' in 1883, Lewis Edson Waterman invented what he called a 'real' fountain pen (Waterman Co., 2007). In the course of one year, six dozen pens were handmade, to which Waterman personally signed a five-year guarantee against any defects. In June, Waterman applied for a US patent on his invention, which was granted on February 12, 1884 (Joonpens, 2007a).

In 1890, Waterman continued experimenting and creating new designs for his pens that became more than just reliable writing instruments; they were objets d'art. In the year 1901, at age 64, Waterman passed away. Frank D. Waterman, Lewis Waterman's nephew, decided to carry on and extend the Waterman name by crossing the Atlantic to conquer Europe (Joonpens, 2007a).

In the 1930s, having been slow to respond to technical and stylistic innovations by the competition, Waterman began to lose ground. During the later " $40 \mathrm{~s}$ and the ' $50 \mathrm{~s}$, the company really ran out of gas, and the remains of the US Waterman operations were finally sold to BIC in 1959, forming the basis of that French firm's American production facilities (Conner, 2007a).

When BIC paid $\$ 1$ million, in 1958 , to acquire a $60 \%$ stake in the Waterman, it had fallen on hard times with the skyrocketing sales of ballpoint pens in the 1950s. Following the acquisition, BIC discovered the full extent of Waterman's financial problems - and added the remaining $40 \%$ as part of the original purchase price. The US operation then took on the name of Waterman-BIC Pen Corporation. The company's entry into the USA, where the BIC was launched as the BIC Stick, was backed by a highly successful advertising campaign based on the slogan, 'writes first time, every time' (Answers.com, 2007a). This show that the new American owners stressed practicality rather than design or craftsmanship, Waterman's pen lost its image of objets d'art.

The same marketing orientation was followed by Gillette, which bought the pen manufacturer in 1987 and has been selling the pens at discount outlets in the USA. Wise (1988) informs that although the sales increased by $40 \%$ since the Gillette takeover, 
Mrs. Gomez, the resigning Waterman's CEO, complained that Gillette's American marketing strategy is devaluing the image of luxury that she had carefully crafted for Waterman in France.

In 2000, Waterman was bought by Sanford Corporation that presents itself as a global leader in the writing instrument and art supply industry (Sanford, 2007). Sanford Corporation belongs to the segment of Office Products of the Newell Rubbermaid Inc. (Newell Rubbermaid, 2007).

Waterman brand is still treasured by collectors and small class of users of high quality pens but by its insertion in a mass market oriented group, it is selling its pens not only in high class outlets as used to be, but also in retailers that can assure more volume of sales.

\subsection{Montblanc Company}

In 1906, in Hamburg, Claus-Johannes Voss, Alfred Nehemias, and August Eberstein founded the Simplo Filler Pen Company, to produce fountain pens. In 1909, a technically improved fountain pen called Montblanc was introduced, and was registered as a trademark, used for all writing instruments produced by the company (Montblanc, 2007).

In 1913, the Montblanc star, representing the snow-covered peak of Mont Blanc, becomes the brand signet for all the writing instruments produced by the Simplo Filler Pen Company. This artisan's device stood for commitment to the highest quality and finest European craftsmanship (Montblanc, 2007).

The launch of the Meisterstück, what would come to be the world's most famous and easily recognised writing instrument, took place in 1924. Montblanc (2007) kept pace, swiftly expanding into more than 60 different countries as an almost ubiquitous name.

In 1934, the company officially assumed the appellative that had already become an internationally known brand, and took the corporate name, Montblanc Simplo GmbH. The company took over a producer of fine leather goods in Offenbach, Germany: Thenceforth, desk accessories were produced under the Montblanc (2007) name.

Montblanc launched in 1955 the ' 60 Line' that represented an entirely new design style, constituting the first major success in the post-war period alongside the traditional Meisterstück series. Several years of commercial business consolidation were to follow. Then, as other industries, and even sister pen manufacturers, seemed to have been anesthetised by emerging computerisation technologies, a breakthrough marketing concept leapt out of Montblanc's corporate offices (Joonpens, 2007b).

The introduction of the ballpoint pen in 1951 must have had an impact on Montblanc that is not recognised even today in Montblanc's history. Fans of the brand, such as Renfer (2007), say that Montblanc was hesitant to enter the ballpoint market, so it hired an outside firm Ballograf to produce its pens. The company did not start to produce its own ballpoints until 1957. The '70s brought some aggressive styles to the Montblanc pen range (Renfer, 2007).

Montblanc made less expensive pens under 'junior' brands like Monterosa, but by the 1970s, the Montblanc name found its way onto pens at most price points. The year 1977 was a turning point for Montblanc, as they were taken over by Dunhill of London. Thenceforth, the lower-priced pens were dropped from the line as the company focused on its luxury offerings. In 1988, both Dunhill and Montblanc were absorbed by the Swiss luxury-goods combine Richemont (Answers.com, 2007b). 
As the new millennium opened, Montblanc has a characteristic, its frequently launching of new collections of writing instruments. Over the decades, Montblanc has created limited masterpieces and special editions with precious materials, such as mother-of-pearl, little pieces of meteorites, gold, silver, precious stones, and many others. Montblanc Company associates its pens to jewels.

\subsection{Parker Company}

George Parker had a simple yet ambitious aim: to make a better pen. And that single, simple vision has powered the Parker Pen Company ever since. In 1888, the Parker Pen Company was founded. In the following year, the first Parker Pen was produced and patented. However, that was only the beginning. Parker's dream of creating better pens led to the major innovation in 1894: the 'Lucky Curve'. This system dramatically reduced the leakage that was a hazard of early fountain pens. 1921 was the year in which Parker's famous icon was born - the Parker Duofold. Although it was considerably larger and more expensive than pens of the time, the Duofold was an instant success (Joonpens, 2007c).

During the Great Depression, many smaller pen companies disappeared as others fell into bankruptcy. Many pen companies decided the next best move was to sell their pens at huge discounts, flooding the markets with cheap pens. Parker decided not to compromise and continued to sell their pens at the price it's had originally set. Many of its older customers appreciated this move as Parker believed its pens had to hold an image - this image which reflected Parker's vision and dreams. In 1939, the first Parker 51 was produced and went on to be a global best-seller, topping the other three American pen companies of that time which survived the Great Depression: Sheaffer, Waterman, and Eversharp (Joonpens, 2007c).

In 1954, Parker's first ball pen, the Jotter, was produced. It was the reaction of Parker's company against the introduction of the ballpoint pen in 1951. After waiting almost nine years to enter the ballpoint market Parker put the Jotter into production in just 90 days (Pentrace, 2007; Parker Co., 2007).

In 1964, the Parker 75 brought a new level of craftsmanship to pens of the era, combining the latest technologies with traditional skills. In celebration of its 100 years of history, 1987 marked the time when Parker returned to its famous icon, the Duofold, by creating the Duofold Centennial Edition. 1993 saw the introduction of the Sonnet Collection, which has since become as much a signature of Parker as the Duofold before it. In 2002, Parker Special Edition 51 combined the classic futuristic styling of the ' 51 ' with the very latest pen technology. In 2004, Parker 100 became the face of Parker for the 21 st century, with a combination of avant-garde looks and an affectionate reinterpretation of the styling of its predecessor, the ' 51 (Joonpens, 2007c; Parker Co., 2007).

Parker, with Sheaffer, was one of the few US firms left standing after the winnowing of the fountain pen industry during the 1950 s and ' 60 s, thanks to its remaining active in the low-price market. Most recently, Parker has changed hands a couple of times; first, they were acquired by Gillette - who had previously purchased Waterman (Conner, 2007b).

In 2000, Parker was bought by Sanford Corporation, which presents itself as a global leader in the writing instrument and art supply industry (Sanford, 2007). Sanford Corporation belongs to the segment of Office Products of the Newell Rubbermaid Inc. (Newell Rubbermaid, 2007). Parker's pens are more related to the design and comfort in 
writing. There are new and recent collections that pay attention to the ergonomics, design, and modern forms to attract young customers.

\section{Discussion and conclusions}

In this section, we analyse the three cases and the impact of the introduction of the ballpoint pen in the writing instruments industry in what is concerned with technological and marketing strategies. The final statement presents the relationship between Schumpeter's concepts of innovation and Christensen's disruptive innovation theory.

\subsection{Technological strategies}

Regarding to the technology, the three companies first reacted by a remaining with the old technology but with a price reduction and, later, on by incorporating new lines of products with the ballpoint technology. However, to stay in line with their positioning in the market, they transform the ballpoint in to luxury goods.

The fountain pen industry competed with a price reduction, but it was impossible to produce a fountain pen with all advantages and facility of usage of the ballpoint pen. Few giants survived such as Waterman, Montblanc, and Parker. These industries needed to change their strategic focus by changing the essence's product (fountain pens) to others associations. Montblanc associated their products to jewels in form of a pen or an object of art, Waterman stressed craftsmanship and design, and Parker maintained the production of luxury pens with high technical quality. However, since sales continued to decrease, the three companies had to adopt the ballpoint technology adapting it to their luxury segment.

In order to maintain its position, Montblanc had to introduce frequent innovations in design and new and expensive materials, what Schumpeter considers as innovation.

Innovation is also in order in the two other companies, not only in the fountain pen but also in the ballpoint pen technology since they are in the highly competitive market.

\subsection{Marketing strategies}

Among the writing instruments, the fountain pen was in the luxury goods niche since its invention in the 19th century. Most of the small number of literate people used pencils since only rich people could buy fountain pens. The invention of the ballpoint pen in the ' 50 s with its low price for the first time made an ink writing instrument available to all classes making a dent on the fountain pen market.

The introduction of the ballpoint pens its very good empirical evidence of what Christensen call disruptive technology. It is also evidence of different types of innovation, as defined by Schumpeter (1985), since the fountain pen industry had to change the focus from product innovation to consciously pursue a marketing innovation opening of a new market and reorganising the industry.

Although, after the attack of the ballpoint pen, all the three fountain pen companies positioned themselves in the luxury goods segment and stabilised their sales but in order to maintain their sales position they still had to make new adjustments. 
After the acquisition of Waterman and Parker by Sanford Corporation, they entered in the segment of high quality office products (see Figure 2). It is important to notice the influence of the corporate group in the marketing strategy of both companies, changing their distribution channels and the product technology.

Montblanc, acquired by the Richemont Group a corporation group oriented to the luxury goods market, continued in its niche.

Figure 2 Reorganisation of the writing instruments industry: acquisitions of Waterman, Parker, and Montblanc

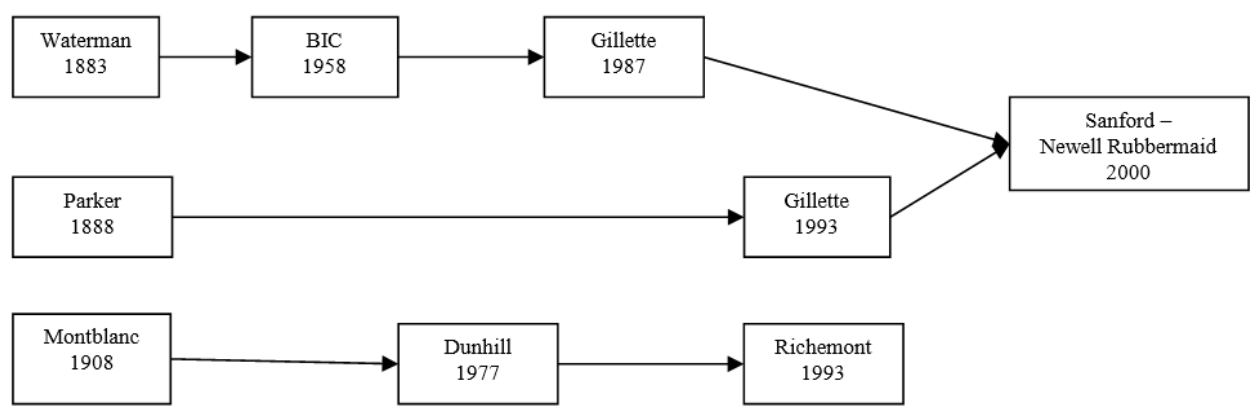

The analysis of this cases leads to the conclusion that the ballpoint pen is truly a good example of Christensen's disruptive technology because it contains all of Schumpeter's types of innovation. There was a new product in the writing instruments industry with the introduction of the ballpoint pen; introduced new processes of production of ink writing instruments; opened a new market; forced the search of new materials both for fountain and ballpoint pens; and forced the reorganisation of the writing instruments industry creating two main market sectors of in the fountain pen industry: the luxury goods and the high-quality office products.

\section{Acknowledgements}

The authors would like to thank to valuable contribution and ideas of Professor Emeritus Edi Madalena Fracasso.

\section{References}

Answers.com (2007a) Société BIC [online] http://www.answers.com/topic/soci-t-bic?cat=biz-fin (accessed 20 December 2007).

Answers.com (2007b) Montblanc International GmbH [online] http://www.answers.com/topic/ montblanc-international-gmbh?cat=biz-fin (accessed 20 December 2007).

Christensen, C.M. (1999) Innovation and the General Management, Irwin McGraw-Hill, Boston.

Christensen, C.M. (2004) Seeing What's Next: Using the Theories of Innovation to Predict Industry Change, Harvard Business School Press, Boston.

Christensen, C.M. and Raynor, M.E. (2003) The Innovator's Solution: Creating and Sustaining Successful Growth, Harvard Business School Press, Boston.

Conner, R.C. (2007a) Waterman's [online] http://www.rickconner.net/penoply/wa.0.html (accessed 20 December 2007). 
Conner, R.C. (2007b) Parker Pens [online] http://www.rickconner.net/penoply/park.0.html (accessed 20 December 2007).

Joonpens (2007a) Waterman History [online] http://www.joonpens.com/upload/Waterman history.php (accessed 20 December 2007).

Joonpens (2007b) Montblanc History [online] http://www.joonpens.com/upload/Montblanc history.php (accessed 20 December 2007).

Joonpens (2007c) Parker History [online] http://www.joonpens.com/upload/Parker_history.php (accessed 20 December 2007).

Lambrou, A. (2005) Fountain Pens of the World, Classic Pens, Los Angeles.

Modis, T. (1997) 'Genetic re-engineering of corporations', Technological Forecasting and Social Change, Vol. 56, No. 2, pp.107-118.

Modis, T. (2003) 'A scientific approach to managing competition', The Industrial Physicist, February/March, pp.22-23.

Montblanc (2007) Montblanc History [online] http://www.montblanc.com (accessed 20 December 2007).

Narayanan, V. (2005) 'Patent and trademark history in the fountain pen industry' [online] http://www.ma.utexas.edu/users/narayana/Academics/Intellectual_Property/termpaper.pdf (accessed 20 December 2007).

Newell Rubbermaid (2007) Segment Overview [online] http://www.newellrubbermaid.com/ newellco/global/segment.jhtml?id=id1 (accessed 20 December 2007).

Parker Co. (2007) Parker History [online] http://www.parkerpen.com/en/discovery/making_of/ timeline (accessed 20 December 2007).

Pennenlux (2007) History of Writing Instruments [online] http://www.pennenlux.com/History\% 20of\%20Writing\%20Instruments_part2.htm (accessed 20 December 2007).

Pentrace (2007) Parker Jotter 50th Anniversary [online] http://www.pentrace.net/penbase/Data Returns/full_article.asp?id=450 (accessed 20 December 2007).

Renfer, M. (2007) History of the Montblanc Firm [online] http://www.montblancs.net/history.html

Sanford (2007) Sanford [online] http://www.sanfordcorp.com/sanford/consumer/jhtml/aboutus/ sanford_about_us_22.jhtml (accessed 20 December 2007).

Schumpeter, J.A. (1985) A teoria do desenvolvimento econômico, Abril, São Paulo.

Utterback, J.M. and Acee, H.J. (2005) 'Disruptive technologies: an expanded view', International Journal of Innovation Management, Vol. 9, No. 1, pp.1-17.

Waterman Co. (2007) Waterman History [online] http://www.waterman.com (accessed 20 December 2007).

Wise, D. (1988) 'Waterman rift: a tearful farewell', The New York Times [online] http://query. nytimes.com/gst/fullpage.html?res=940DE4DB1F38F935A25751C1A96E948260\&sec= \&spon $=($ accessed 16 December 2007). 


\section{Appendix}

Table A1 Major fountain pen companies

\begin{tabular}{lccc}
\hline Company & Year of foundation & Present status & Country \\
\hline Waterman & 1882 & Active & France \\
Parker & 1891 & Active & UK \\
Montblanc & 1906 & Active & Germany \\
Montegrappa & 1912 & Active & Italy \\
Omas & 1919 & Active & Italy \\
Aurora & 1919 & Active & Italy \\
Namiki & 1924 & Active & Japan \\
Mabie Todd & 1860 s & 1958, closed & Anglo-American \\
Thomas de la Rue & 1881 & 1957, closed & UK \\
Kaweco & 1892 & 1970, closed & Germany \\
Moore & 1898 & 1950 s, closed & USA \\
Conklin & 1898 & 1940 s, closed & USA \\
Whitworth & 1910 & 1915, closed & UK \\
Le Boeuf & 1918 & 1936, closed & USA \\
Dunn & 1921 & 1924, closed & USA \\
\hline
\end{tabular}

Source: Adapted from Narayanan (2005) 